\title{
Application of Biochar in Stormwater Treatment: Experimental and Modeling Investigation
}

\author{
Md Sazadul Hasan ${ }^{1}$ (D), Raul Vasquez ${ }^{2}$ and Mengistu Geza ${ }^{1, *(D)}$ \\ 1 Civil and Environmental Engineering, South Dakota School of Mines and Technology, \\ Rapid City, SD 57701, USA; mdsazadul.hasan@mines.sdsmt.edu \\ 2 South Dakota Department of Environment \& Natural Resources, Rapid City, SD 57701, USA; \\ raul.vasquez@state.sd.us \\ * Correspondence: stu.geza@sdsmt.edu; Tel.: +1-720-982-5359
}

Citation: Hasan, M.S.; Vasquez, R.; Geza, M. Application of Biochar in Stormwater Treatment: Experimental and Modeling Investigation. Processes 2021, 9, 860. https://doi.org/ $10.3390 /$ pr9050860

Academic Editor: Mauro Giorcelli

Received: 16 April 2021

Accepted: 10 May 2021

Published: 13 May 2021

Publisher's Note: MDPI stays neutral with regard to jurisdictional claims in published maps and institutional affiliations.

Copyright: (c) 2021 by the authors. Licensee MDPI, Basel, Switzerland. This article is an open access article distributed under the terms and conditions of the Creative Commons Attribution (CC BY) license (https:// creativecommons.org/licenses/by/ $4.0 /)$.

\begin{abstract}
This research investigated the removal of heavy metal ions $(\mathrm{Cd}, \mathrm{Cu}, \mathrm{Pb}$, and $\mathrm{Zn})$ and metalloid (As) common to stormwater runoff onto biochar-based media arranged in multiple configurations. Laboratory scale column experiments were conducted to quantify heavy metal removal efficiencies using sand, biochar, and nZVI-modified biochar (BC-nZVI) in four media configurations: a homogeneous mixture of sand and biochar (BCM); biochar layered in sand (BCL); BC-nZVI layered in sand (BCZ); and sand as a control. An inverse modeling approach was implemented to measured moisture and experimental data to determine media hydraulic parameters $\left(\theta_{\mathrm{r}}, \theta_{\mathrm{s}}, \alpha, \mathrm{n}\right.$ and $\left.\mathrm{K}_{\mathrm{s}}\right)$ and adsorption coefficients. The experiment was conducted using laboratory synthesized stormwater over 200 days at a rate of $5 \mathrm{~cm} /$ day. BCZ exhibited an excellent removal (99\%) of As due to the high attachment to nZVI, via surface complexations. Biochar with abundant surface oxygen functional groups exhibited a great (99\%) removal of $\mathrm{Cd}$ and $\mathrm{Zn}$ in both BCL and BCM columns. Water contents were observed 66.0, 44.3, 41.4, and 7.2\% for BCL, BCM, BCZ, and sand, respectively. The attachment coefficients varied from 21.5 to $44.9,16.1$ to $19.3,18.8$ to 26.0 , and 9.6 to $19.9 \mathrm{~L} / \mathrm{kg}$ for BCL, BCM, BCZ, and sand, respectively. This study's output provides useful information for stormwater management practices.
\end{abstract}

Keywords: heavy metals; stormwater treatment; biochar; HYDRUS modeling

\section{Introduction}

The expansion of urban regions increases impervious surface area and has the potential to impact water environments. Hydrologic changes associated with urban growth are increased runoff peak, runoff volume, and reduced time to peak [1]. Changes in characteristics of urban runoff are not the only effects of urbanization; water quality is also impacted. Urban runoff contains various amounts of metals, organic compounds, suspended solids, and inorganic compounds. Heavy metals originate from tire wear, automobile exhausts, road asphalt, and fuel combustion deposits accumulating on roadways [2]. During rainfall and snowmelt events, metals are transported to nearby surface waters, affecting the health of the ecosystem and contaminating groundwater. Cadmium, copper, lead, mercury, nickel, and zinc are common metals found in stormwater and are listed on the EPA's priority pollutants [3]. Heavy metals are known to cause health issues in humans and can enter the body by inhalation, skin absorption, and digestion. Health problems associated with heavy metal exposure include respiratory system damage, nervous system damage, and cancer [4]. Established treatment methods of urban runoff include liquid extraction, precipitation, reverse osmosis, and ion exchange, methods which achieve acceptable discharge concentrations; however, they are not always economical or technically feasible [5].

Research has expanded to inexpensive adsorbents that have an affinity for metals. For example, early research of filter materials used for the adsorption of heavy metals included peanut hulls, chitosan, zeolite, and mulch [6-8], and recent materials used for heavy metal 
adsorption are calcite, sand, iron fillings, nanoscale metal oxides, zero-valent iron, biochar, or combinations of these materials [9-11]. Best management practice (BMP) technologies have been developed to manage urban runoff and improve water quality [12], and lowimpact development (LID) bioretention cells are one BMP found to be an effective means of reducing heavy metals found in runoff [13]. The typical bioretention cell uses porous media covered with hardwood mulch to perform water treatment. Often, vegetation is used to promote evapotranspiration, biological activity, and pollutant uptake [14]. The common bioretention media has a top layer of mulch (2-3 inches) followed by a homogenous mixture that is more than $80 \%$ sand, $8-12 \%$ fines, and $3-5 \%$ organic matter [15]. Bioretention cells were fabricated successfully using variations of sand, silt, clay, and organic matter in two Maryland locations to monitor heavy metal removal performance, and median values for effluent percent removals based on combined data sets (both cells) were $76 \%$ copper, $57 \%$ lead, and $83 \%$ zinc [14]. A similar study by monitoring a bioretention shoulder in Seattle, Washington, consisting of washed gravel and a soil mixture, $70 \%$ sand and $30 \%$ organic compost, removed $79 \%$ of copper and $86 \%$ zinc [16]. Moreover, peanut hulls, zeolites, activated carbon, calcite, iron, and mulch have been used in these types of experiments to absorb different heavy metals (i.e., $\mathrm{Cd}, \mathrm{Cu}, \mathrm{Pb}, \mathrm{Ni}, \mathrm{Cr}$, and $\mathrm{Zn}$ ) common to stormwater runoff $[8,10,17,18]$.

Biochar is another emerging material, which is both abundant and inexpensive to produce [19], and exhibits a huge potential for applications in stormwater treatment [20-22]. Additionally, biochar as a soil amendment increases agricultural productivity by improving hydraulic properties, water retention, nutrient use efficiency, and soil fertility [23]. The common feedstock used to create biochar includes oak trees, apple trees, rice husk, rice hull, and manure [19]. A lot of material would otherwise accumulate in landfills. The production of biochar creates carbon that is more stable than the original feedstock that has the potential to decompose and create $\mathrm{CO}_{2}$ gases that enter the atmosphere, and energy created by the pyrolysis of biomass includes syngas, bio-oil, and process heat [24]. The physical and chemical properties of biochar create an affinity for the removal of heavy metals [25]. One reason is the high cation exchange capacity, due to the negatively charged oxygen functional groups present on the biochar surface [26]. Another reason is the porous structures created from pyrolysis processing: chemical, and physical properties change when pyrolyzed at different temperatures $\left(400,500,600,700\right.$, and $\left.800{ }^{\circ} \mathrm{C}\right)$ [19]. Lower temperatures yielded biochar with a higher volatile matter content composition, while higher temperatures yielded biochar with more aromatic compounds [27]. The common mechanisms that account for metal adsorption from water include electrostatic interactions between metals and biochar surface, cation exchange between metals and protons or alkaline metals on biochar surface, metal complexation with functional groups and the aromatic structure of biochar, metal precipitation to form insoluble compounds, reduction of metal species and subsequent adsorption of reduced species, etc. [28].

Nanoparticles have successfully been used to remove various contaminants including chlorinated methane, chlorinated benzenes, pesticides, organic contaminants, inorganic ions, and heavy metals [29]. Nanoparticles are particularly effective when used in situ in soil, where they can be effectively transported by water flow. Nanoparticles can also be pressure-injected or gravity-fed in slurries to treatment zones. Another attribute of nanoparticles is that they can stay suspended in soils for extended periods. In the case of heavy metal adsorption from water solutions, nanoscale zero-valent iron (nZVI) and nanoscale metal oxides, including ferric oxides, manganese oxides, titanium oxides, aluminum oxides, and cerium oxides have been studied extensively [30,31]. nZVI is a nanoparticle gaining recognition in environmental remediation due to its cost-effectiveness, significant surface area, and reducing properties [32]. However, nZVI is unstable in aqueous solutions, making its use for environmental applications challenging [29]. Research shows that support materials such as clays, resins, and carbon materials can enhance dispersion and stability [33]. The utilization of biochar as porous carriers for supporting nZVI can also be efficient and economically beneficial. Recent studies regarding metals, E. coli, and nitrate 
removal from stormwater demonstrated great efficiencies of amino- and nZVI- modified biochar [9,34-36]. Biochar-based adsorbents, including the nZVI modified form, exhibited excellent performance in removing As from water, primarily due to it having a large surface area, abundant functional groups, and favorable chemical properties for the attachment [37]. Additionally, metal removal efficiency increases with increasing nZVI:biochar mass ratios, where efficiencies reached $100 \%$ when the addition of $n Z V I /$ biochar was $>2: 1$ [34]. All the media mentioned above have capabilities to remove different contaminants from stormwater. However, compared to homogeneous media, utilizing a combination of local sand and alternative filter media demonstrated improved nutrient and heavy metal removal efficiencies in stormwater treatment [38]. Therefore, different configurations of biochar and sand media need to be investigated in a bioretention cell for better efficiency.

This research includes experimental and numerical modeling approaches to investigate the heavy metal removal efficiencies of different media configurations from stormwater to implement the results in bio-retention filter media. We examined retention capabilities of heavy metals such as $\mathrm{Cd}, \mathrm{Cu}, \mathrm{Pb}$, and $\mathrm{Zn}$, and a metalloid (As) along with hydraulic properties of commercially available biochar distributed in sand (layer, and homogenous mixture), nZVI modified biochar (BC-nZVI) (layer), and sand as a control. The experiment was conducted in larger columns to better represent field conditions, compared to adsorption experiments that rely on batch reactors to test adsorbent performance. The experimental result demonstrated the excellent ability of BC-nZVI layered sand media to remove As and biochar layered sand media to remove $\mathrm{Cd}$ and $\mathrm{Zn}$. Moreover, HYDRUS 2D, a numerical model for unsaturated zone flow and contaminant transport, inversely fitted the measured moisture data and investigated the hydraulic properties of sand, biochar, and BC-nZVI. These parameters were further implemented to HYDRUS 2D models and determined adsorption coefficient $\left(\mathrm{K}_{\mathrm{d}}\right)$ values for each metal $(\mathrm{Cd}, \mathrm{Cu}, \mathrm{Pb}$, and $\mathrm{Zn})$ and metalloid (As) in each media. These study findings will provide insightful information about efficient filter media for heavy metal removal, likely for stormwater treatment and management practices.

\section{Materials and Methods}

\subsection{Experimental Investigation}

\subsubsection{Column Media and Reagents}

The four media combinations (described in Section 2.1.3) consisting of sand, biochar, nanoscale zero-valent iron (nZVI), and modified biochar (BC-nZVI) were studied for their metal removal efficiencies. Sand (Mastercraft) was purchased from a local store (Menards, Rapid City, SD, USA) and sieved to 40-50 mesh (0.3-0.425 mm) to maintain a homogeneous size of $0.36 \mathrm{~mm}$, and was termed as 'sand'. Commercially available powder biochar ( $\leq 0.3 \mathrm{~mm}$ ) was purchased from Biochar Now (Loveland, CO, USA) and termed as 'biochar'. According to the manufacturer, this biochar was produced from pinewood biomass under a slow pyrolysis process at a temperature of $600{ }^{\circ} \mathrm{C}$.

BC-nZVI was synthesized in the laboratory by adding biochar in iron solution and adding a strong reducing agent, $\mathrm{NaBH}_{4}$. We upscaled the synthesis procedure of BC-nZVI which was described elsewhere [39]. Briefly, using 5-gallon buckets, biochar (removed fine particles by sieving with mesh $200(0.074 \mathrm{~mm})$ was weighed to $0.7 \mathrm{~kg}$ and added into $10 \mathrm{~L} 0.075 \mathrm{~mol} / \mathrm{L} \mathrm{FeSO}_{4} \cdot 7 \mathrm{H}_{2} \mathrm{O}$ (ferrous sulphate heptahydrate) solution at a $\mathrm{pH}$ of 5.0. Nitrogen gas was purged into the solution for $2 \mathrm{~h}$ to remove dissolved $\mathrm{O}_{2}$ that may have accumulated during preparation. Dropwise addition of $5 \mathrm{~L} 0.215 \mathrm{~mol} / \mathrm{L} \mathrm{NaBH}_{4}$ (sodium borohydride) was then added by burette and stirred constantly so the nZVI particles would adhere to the surface of the biochar. The reaction equation for iron sulfate heptahydrate and sodium borohydride is shown in Equation (1):

$$
4 \mathrm{Fe}^{3+}+3 \mathrm{BH}_{4}^{-}+9 \mathrm{H}_{2} \mathrm{O} \rightarrow 4 \mathrm{Fe}^{0}+3 \mathrm{H}_{2} \mathrm{BO}_{3}^{-}+6 \mathrm{H}_{2}+12 \mathrm{H}^{+}
$$

Stirring continued for 45 min after all $\mathrm{NaBH}_{4}$ was dissolved into the biochar iron solution. The biochar was then filtered by 200 mesh sieves and washed thoroughly with 
ethanol on Whatman Shark Skin Filter Papers. The separated nZVI modified biochar was then dried in a vacuum oven for $24 \mathrm{~h}$ and termed as 'BC-nZVI'. The ratio of biochar to nZVI was maintained at 1:15. $\mathrm{NaBH}_{4}$ and $\mathrm{FeSO}_{4} \cdot 7 \mathrm{H}_{2} \mathrm{O}$ were research-grade and purchased from Sigma-Aldrich, St. Louis, MO, USA.

\subsubsection{Stormwater Solution}

The stormwater solution for this study was prepared by mixing clean synthetic stormwater $[22,40]$ (components are shown in Table 1 ) and heavy metal solution consisted of As, Cd, $\mathrm{Cu}, \mathrm{Pb}$, and $\mathrm{Zn}$ at "first flush" urban stormwater concentrations [10]. Metal concentrations (shown in Table 2) used for the experiment were at higher ranges than normally observed in stormwater to reduce the amount of time required for a breakthrough to occur. This was not expected to affect the conclusions, because the main objective of the experiment was to evaluate the relative performance of the media configuration used in the study.

Table 1. Clean synthetic stormwater composition.

\begin{tabular}{|c|c|c|}
\hline \multirow{2}{*}{ Constituents } & \multicolumn{2}{|c|}{ Concentration $[22,40,41]$} \\
\hline & $(\mathrm{mM})$ & $\left(\mathrm{mg} \cdot \mathrm{L}^{-1}\right)$ \\
\hline $\mathrm{Ca}^{2+}$ & 0.750 & 30.10 \\
\hline $\mathrm{Mg}^{2+}$ & 0.075 & 1.80 \\
\hline $\mathrm{Na}^{+}$ & 1.750 & 40.30 \\
\hline $\mathrm{NH}^{4+}$ & 0.072 & 1.30 \\
\hline $\mathrm{SO}_{4}^{2-}$ & 0.330 & 31.70 \\
\hline $\mathrm{HCO}^{3-}$ & 1.000 & 61.00 \\
\hline $\mathrm{Cl}^{-}$ & 1.700 & 60.30 \\
\hline $\mathrm{NO}_{3}^{-}$ & 0.072 & 4.50 \\
\hline $\mathrm{H}_{2} \mathrm{PO}_{4}^{-}$ & 0.016 & 1.60 \\
\hline
\end{tabular}

Table 2. Metal concentrations in actual stormwater, concentrations considered in this study, and the source chemicals used in the preparation of the stormwater solution.

\begin{tabular}{cccc}
\hline Metal/Metalloid Ion & $\begin{array}{c}\text { Average Range in Actual } \\
\text { Stormwater }\left(\mathbf{m g} \cdot \mathbf{L}^{-1}\right) \mathbf{[ 1 0 , 4 2 ]}\end{array}$ & $\begin{array}{c}\text { Concentration }\left(\mathbf{m g} \cdot \mathbf{L}^{-1}\right) \\
\text { in This Study }\end{array}$ & Source Chemical \\
\hline $\mathrm{As}^{3+}$ & $0.00005-2.00$ & 5 & $\mathrm{NaAsO}_{2}$ \\
\hline $\mathrm{Cd}^{2+}$ & $0.00005-13.73$ & 30 & $\mathrm{CdCl}_{2}$ \\
\hline $\mathrm{Cu}^{2+}$ & $0.00006-1.41$ & 2.5 & $\mathrm{CuSO}_{4}$ \\
\hline $\mathrm{Pb}^{2+}$ & $0.00057-26.00$ & 25 & $\mathrm{~Pb}_{\left(\mathrm{NO}_{3}\right)_{2}}$ \\
\hline $\mathrm{Zn}^{2+}$ & $0.0007-22.00$ & 25 & $\mathrm{ZnSO}_{4}$ \\
\hline
\end{tabular}

The source chemicals of metalloid and metal candidates were sodium arsenite $\left(\mathrm{NaAsO}_{2}\right)$ for arsenic, cadmium chloride $\left(\mathrm{CdCl}_{2}\right)$ for cadmium, copper sulphate $\left(\mathrm{CuSO}_{4}\right)$ for copper, lead nitrate $\left(\mathrm{Pb}\left(\mathrm{NO}_{3}\right)_{2}\right)$ for lead, and zinc sulphate $\left(\mathrm{ZnSO}_{4}\right)$ for zinc. Metal solutions were prepared by adding the salts at the appropriate amount to deionized water and stirred for $30 \mathrm{~min}$ using a magnetic stirrer. A 5.0 L sample of stormwater was prepared each time for the large volume of stormwater solution required over 200 days of the experiment. $\mathrm{NaAsO}_{2}$ and $\mathrm{Pb}\left(\mathrm{NO}_{3}\right)_{2}$ were purchased through Sigma-Aldrich; $\mathrm{NaAsO}_{2}$ was $\geq 90 \%$ purity and $\mathrm{Pb}$ $\left(\mathrm{NO}_{3}\right)_{2}$ was ACS reagent grade. $\mathrm{CdCl}_{2}, \mathrm{CuSO}_{4}$, and $\mathrm{ZnSO}_{4}$ were purchased through Fisher Scientific at ACS reagent grade.

\subsubsection{Column Setup}

The column experiment used four different combinations of media in triplicate for a total of 12 columns (Figure 1). The columns were made from a clear acrylic pipe that 
were $15 \mathrm{~cm}$ in diameter and $60 \mathrm{~cm}$ length. The bottom of the columns was capped with 6-inch quick caps (FERNCO Quick Cap) with 0.5-inch holes drilled in the center and lined with cheesecloth to keep fine sand from exiting the column when dosed with the metal solution. A PVC outflow pipe (0.5-inch) was pushed tightly into the bottom of the cap. The three combinations were $\mathrm{C} 1$ : a homogeneous sand (sand) as a control, $\mathrm{C} 2$ : a homogenous mixture of biochar and sand (BCM), C3: biochar layer between two sand layers (BCL), and C4: BC-nZVI between two sand layers (BCZ). Both biochar media were $5 \%$ by weight in all cases, which is a common amendment ratio found in the literature $[43,44]$. A $3 \mathrm{~cm}$ pea gravel layer was placed at the top and bottom of each column for proper distribution of stormwater along the cross-section.

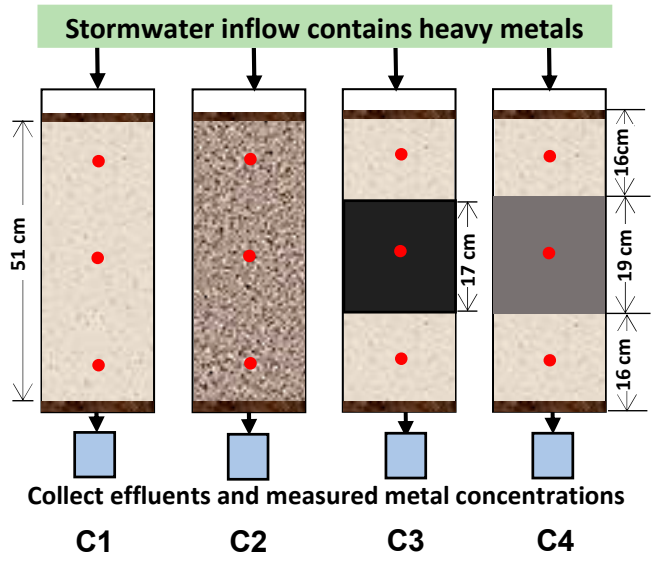

Sand
BC mixed with sand
Biochar
BC-nZVI
- Soil Moisture sensor
C1: Sand - Homogeneous sand
C2: BCM - Biochar Mixed with sand
C3: BCL - Biochar layered with sand
C4: BCZ - BC-nZVI layered with sand

Figure 1. Column media with sand, biochar, and nZVI modified biochar (BC-nZVI) in four different configurations. Each column configuration was triplicated in the experiment.

All the column and media dimensions are shown in Figure 1. All columns were fed by a single influent tank to maintain the constituent's uniformity in the stormwater solution. A 12-channel peristaltic pump (Golander LLC, BT100S-1, Pump head DG10-12) was utilized to maintain a constant dose of stormwater solution to the top of the columns at a flux of $5.0 \mathrm{~cm} \cdot \mathrm{day}^{-1}$. The same inflow of stormwater solutions was maintained through all columns for 200 days. The effluents from each column were collected weekly and quantified the metal concentrations using inductively coupled plasma mass spectrometry (7900 ICPMS, Agilent, Santa Clara, CA, USA). The average metal concentration of triplicated columns was considered for the effluent concentration of that configuration type.

Moreover, to investigate water retention abilities of the media configurations and to evaluate hydraulic parameters for the modeling investigation (using HYDRUS 2D, V 2.05), moisture sensors (SM100, SMEC 300, Spectrum technologies Inc., 3600 Thayer Court, Aurora, IL, USA) were placed (Figure 1) in three areas of the columns and moisture percentages were recorded hourly. Sensor one was placed five centimeters above the bottom of the column, sensor two was placed $25 \mathrm{~cm}$ above the bottom of the column, and sensor three was placed at the top of the column, $5 \mathrm{~cm}$ below the surface. A micro-station (1400 series watchdog, spectrum technologies) recorded soil moisture hourly until the program came up with reasonable parameters and extracted them with a laptop. Initial saturated hydraulic conductivity readings were measured by a hydraulic conductivity instrument (KSAT, Metering group, 2365 NE Hopkins Court, Pullman, WA, USA) for all media (sand, biochar, nZVI biochar) to estimate reasonable ranges for the modeling investigation.

\subsection{Media Characterization and Data Analysis}

A scanning electron microscope, SEM (Zeiss Supra 40 Variable-Pressure, ZEISS Group, Maple Grove, MN, USA), equipped with energy-dispersive X-ray spectroscopy (EDS) was utilized to observe the surface morphologies of biochar before and biochar after nZVI modification. Brunauer-Emmett-Teller (BET) surface area of BC-nZVI was measured by 
$\mathrm{N}_{2}$ adsorption using a surface area analyzer (Gemini VII 2390, Micromeritics, Norcross, GA, USA). Moreover, the surface functional groups on biochar and BC-nZVI play an important role in metal interactions with the media. Thus, Fourier-transform infrared (FTIR) spectroscopy (Thermo Fisher Scientific Nicolet iS10) was used to identify functional groups present on the biochar. The FTIR used diamond attenuated total reflection (ATR) for analysis, and the sample required potassium bromide $(\mathrm{KBr})$ pellet preparation. Biochar $(3 \mathrm{mg}$ ) was added to $\mathrm{KBr}(300 \mathrm{mg})$ and ground by mortar and pestle. The ground powder was then placed in a die and put in a hydraulic press under 30 tons of pressure for one minute. The disk-shaped pellet was then put into FTIR for absorbance analysis. Both biochar and nZVI modified biochar were analyzed using the same method as described.

Metal removal efficiency (\%) of each media configuration was calculated using Equation (2):

$$
\text { Metal removal efficiency }(\%)=\frac{\left(\mathrm{C}_{0}-\mathrm{C}_{\mathrm{e}}\right)}{\mathrm{C}_{0}} \times 100
$$

where $C_{0}$ is the initial concentration of metals in the solution $(\mathrm{mg} / \mathrm{L})$, and $\mathrm{C}_{\mathrm{e}}$ is the equilibrium concentration of metals in the effluent solution $(\mathrm{mg} / \mathrm{L})$.

\subsection{Modeling Investigation}

\subsubsection{Modeling of Hydraulic Parameters}

The HYDRUS 2D program is a finite element model for simulating the movement of water, heat, and multiple solutes in variably saturated media [45]. The HYDRUS 2D model uses the two-dimensional form of the Richards equation (Equation (3)) for flow simulation [45].

$$
\frac{\partial \theta}{\partial t}=\frac{\partial}{\partial x_{i}}\left[K\left(K_{i j} \frac{\partial h}{\partial x_{j}}+K_{i z}\right)\right]-S
$$

where $\theta$ is the volumetric water content, $h$ is the pressure head $[\mathrm{L}], \mathrm{S}$ is the sink term $[1 / \mathrm{T}]$, $x_{i}$ and $x_{j}$ are spatial coordinates [Length], $t$ is time [T], $K_{i j}$ and $K_{i z}$ are the components of dimensionless anisotropy tensor, and $\mathrm{K}$ is unsaturated hydraulic conductivity [Length/ $\mathrm{T}]$.

The model implemented the soil hydraulic functions proposed by Van Genuchten and Mualem $[46,47]$ to describe the soil water retention curve using the following formulae, Equations (4)-(8):

$$
\begin{aligned}
& \theta(h)=\left\{\theta_{\mathrm{r}}+\frac{\theta_{\mathrm{s}}-\theta_{\mathrm{r}}}{\left[1+|\alpha \mathrm{h}|^{\mathrm{n}}\right]^{\mathrm{m}}}\right\} \mathrm{h}<0 \\
& \theta(\mathrm{h})=\theta_{\mathrm{s}} \mathrm{h} \geq 0
\end{aligned}
$$

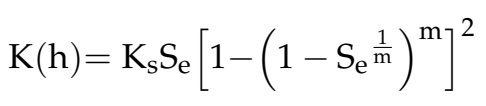

$$
\begin{aligned}
& \mathrm{m}=1-\frac{1}{\mathrm{n}} \mathrm{n}>1 \\
& \mathrm{~S}_{\mathrm{e}}=\frac{\theta-\theta_{\mathrm{r}}}{\theta_{\mathrm{s}}-\theta_{\mathrm{r}}}
\end{aligned}
$$

where $\theta_{\mathrm{r}}$ is the residual water content $\theta_{\mathrm{s}}$ is the saturated water content, $\alpha$ is inverse of the air entry value [1/Length], $\mathrm{K}_{\mathrm{s}}$ is the saturated hydraulic conductivity [Length/T], $\mathrm{n}$ is the pore size distribution index, and $\mathrm{S}_{\mathrm{e}}$ is the effective water content.

Soil moisture data collected from sensors were entered into HYDRUS 2D software and inversely modeled to estimate media hydraulic parameters. The objective of using inverse modeling was to determine model parameter values $\left(\theta_{r}, \theta_{s}, \alpha\right.$, n and $\left.K_{s}\right)$ that provide the best attainable fit between model predictions and recorded observations.

\subsubsection{Modeling of the Metal Transport}

Inverse modeled hydraulic parameters were used to evaluate heavy metal transport within the columns. The same mesh, boundary, and initial conditions used to create 
hydraulic parameters were used to model heavy metal transport. Influent concentrations were taken as mentioned in Table 2, and concentrations were verified at the time of solution mixing to assure proper dissolution. Effluent concentrations were measured by ICP-MS and then averaged among triplicate columns. Effluent metal concentrations measured during experiments were implemented to estimate the transport parameter $\left(\mathrm{K}_{\mathrm{d}}\right)$.

HYDRUS 2D numerically solves the following convection-diffusion equations (Equations (9) and (10)) with zero-order and first-order reaction and sink terms. The Galerkin finite element method is used in this model to solve the governing equation subjected to appropriate initial boundary conditions [45].

$$
\begin{gathered}
\frac{\partial \theta C}{\partial t}+\rho_{b} \frac{\partial S}{\partial t}=\frac{\partial}{\partial x}\left(\theta D \frac{\partial C}{\partial x}\right)-\frac{\partial q C}{\partial x} \\
\rho_{b} \frac{\partial S}{\partial t}=\theta K_{d} C
\end{gathered}
$$

where $\theta$ is the volumetric water content, $C$ is the metal concentration in the liquid phase, $\mathrm{t}$ is time, $\rho_{\mathrm{b}}$ is the bulk density of media, $\mathrm{S}$ is the metal concentration on the solid phase, $\mathrm{x}$ is the spatial coordinate, $\mathrm{D}$ is the hydrodynamic dispersion coefficient, $\mathrm{q}$ is flow rate, and $K_{d}$ is the first-order attachment coefficient.

\section{Results and Discussion}

\subsection{Media Characteristics}

SEM images of biochar before and after nZVI modification (Figure 2) depicted the differences in surface morphologies due to modification. For example, sharp edges of biochar were evident from Figure $2 \mathrm{a}$, which reflected the surface roughness, and the surface of biochar included macro and mesopores (Figure 2b). However, the presence of foreign materials on the biochar was evident in Figure 2c,d.
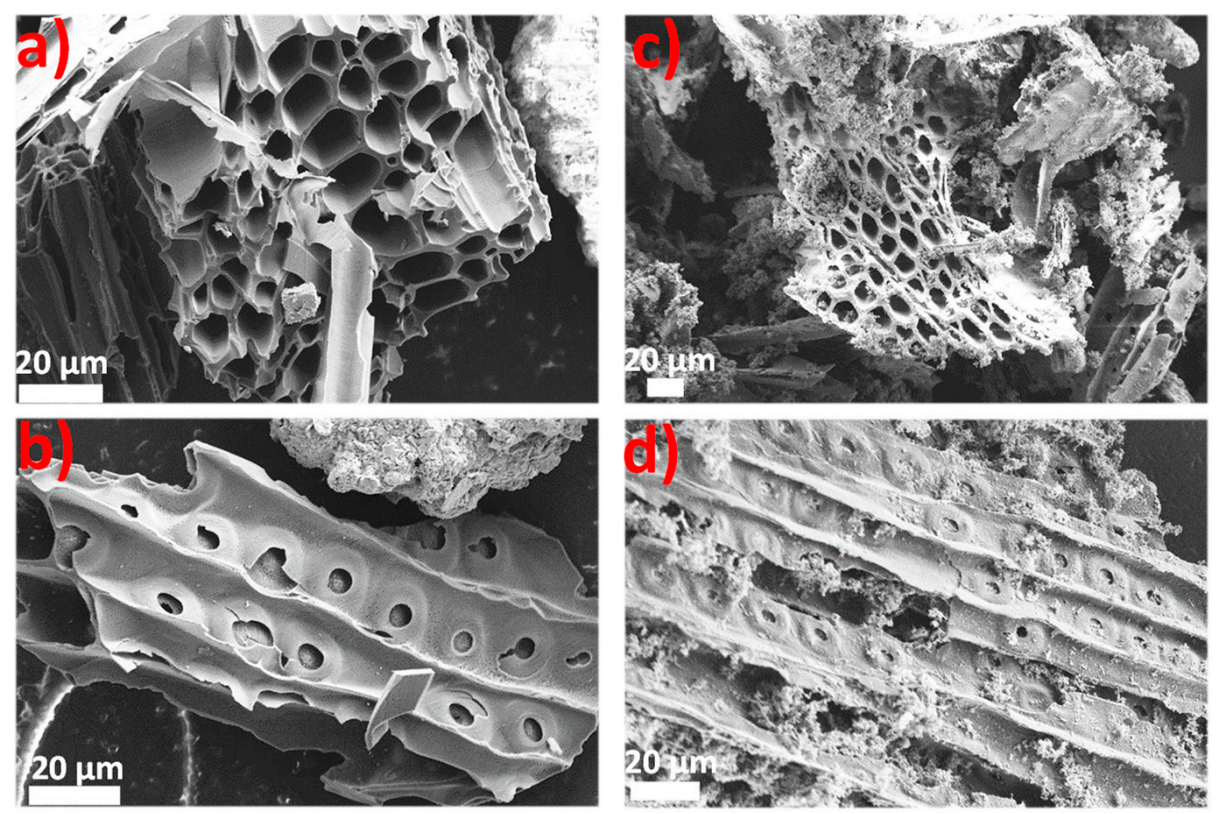

Figure 2. SEM images of biochar before and after the modification as BC-nZVI: (a) Sharp edges of biochar with high porosity; (b) Smooth surface of biochar with macropores; (c) Iron (nZVI) particles accumulated in the sharp edges in BC-nZVI; and (d) Iron (nZVI) particles distributed on the surface in BC-nZVI.

An EDS site mapping (Figure 3) confirmed the presence of nZVI, and the porous areas of biochar seemed to have an agglomeration of nZVI, possibly due to the nanoparticles 
attaching and accumulating to the rough edges. The EDS elemental analysis provides a rough estimation of the actual elemental weight percentage; however, it does give a reliable visualization of the location of elements found in the specimen. Figure 3 shows the three most abundant elements in the sample $(\mathrm{C}, \mathrm{Fe}$, and $\mathrm{O})$, where carbon and oxygen were evenly distributed throughout the sample; this could be attributed to biochar's oxygenrich functional groups. However, the distributed coating of nZVI supported the decent modification of biochar.
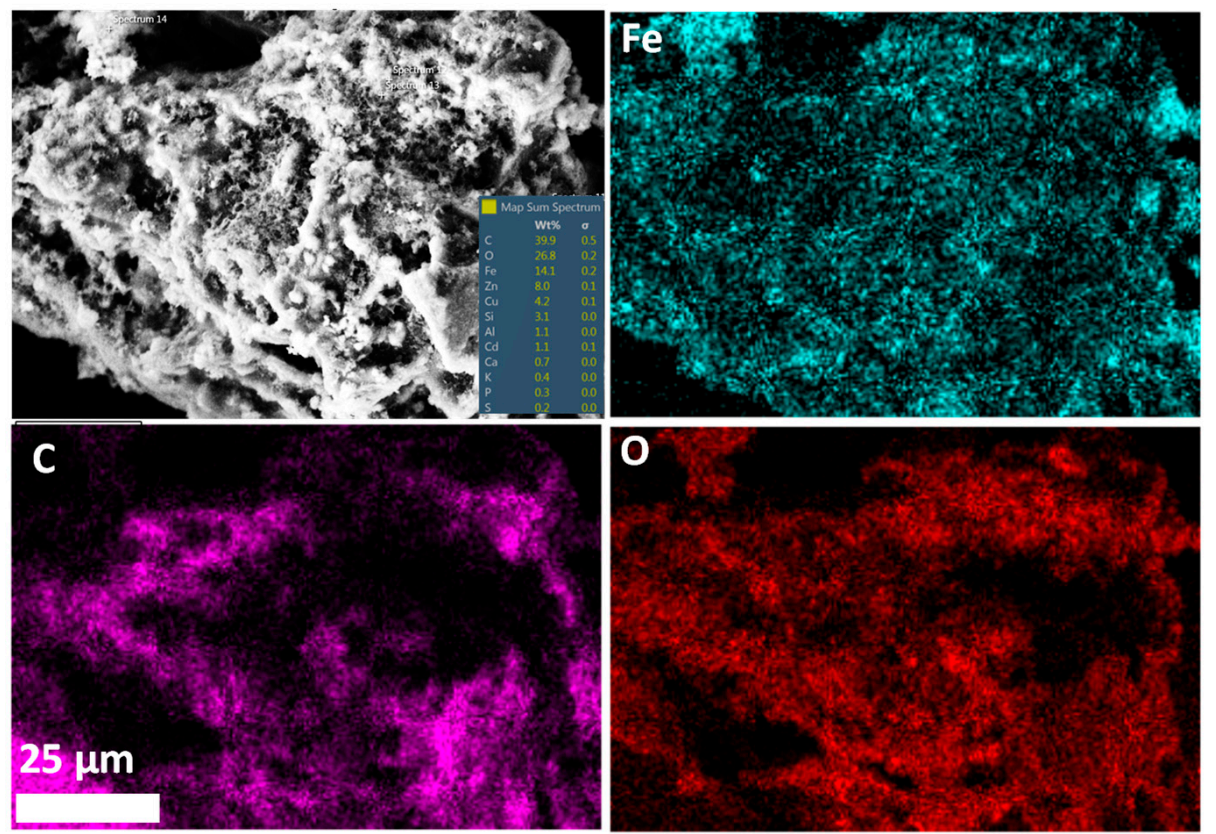

Figure 3. EDS mapping of BC-nZVI depicted that $\mathrm{C}, \mathrm{O}$, and Fe were the most plentiful components on the surface of biochar. The presence of distributed Fe confirmed a proper nZVI modification of biochar.

The BET surface area analysis showed that the surface area drastically reduced from $400 \mathrm{~m}^{2} / \mathrm{g}$ to $23.94 \mathrm{~m}^{2} / \mathrm{g}$ after the modification of biochar to BC-nZVI. This is attributable to filtering out fine particles during the modification process and the occupancies of biochar pores by nZVI particles after modification, as seen from SEM-EDS analysis. The FTIR spectrum confirmed the presence of abundant functionals groups on biochar and BCnZVI surfaces shown in Figure 4. The spectra of biochar proved the presence of carbon and oxygen functional groups such as $-\mathrm{OH}\left(\right.$ at $\left.3405 \mathrm{~cm}^{-1}\right)$, aliphatic $\left(2920 \mathrm{~cm}^{-1}\right), \mathrm{C}=\mathrm{O}$ $\left(1617 \mathrm{~cm}^{-1}\right)$, aromatic ring $\left(1384 \mathrm{~cm}^{-1}\right)$, and etheric C-O-C group $\left(1088 \mathrm{~cm}^{-1}\right)$ [48]. Spectra of BC-nZVI retained similar carboxyl and hydroxyl functional groups similarly to biochar, but with a small peak shift. Additional peaks in the BC-nZVI spectra between 500 and $600 \mathrm{~cm}^{-1}$ represented an $\mathrm{Fe}-\mathrm{O}$ bond. A previous study observed a peak at $567 \mathrm{~cm}^{-1}$ that was related to $\mathrm{Fe}-\mathrm{O}$ bending, and a peak at $578 \mathrm{~cm}^{-1}$ which indicated the presence of $\mathrm{Si}-\mathrm{O}-\mathrm{Fe}$ bonding for iron-modified media [49]. Significant peaks for the corresponding absorbance are displayed in Table S1.

\subsection{Media Metal and Metalloid Removal Performance Evaluations}

The performance of each column configuration was evaluated from the ability to retain metals/metalloid over time and removal efficiencies at 200 days. The effluent metal/metalloid concentrations over the experimental period and the final removal efficiencies at the end of the experiment for each media configuration are presented in Figure 5 and Figure 6, respectively. 


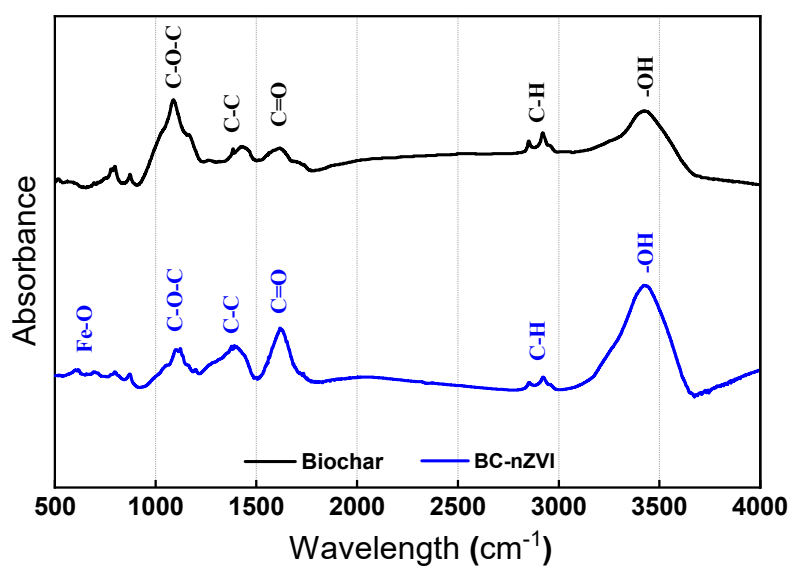

Figure 4. FTIR spectra of biochar and BC-nZVI (nZVI modified form of biochar) represented the functional groups on their surfaces.
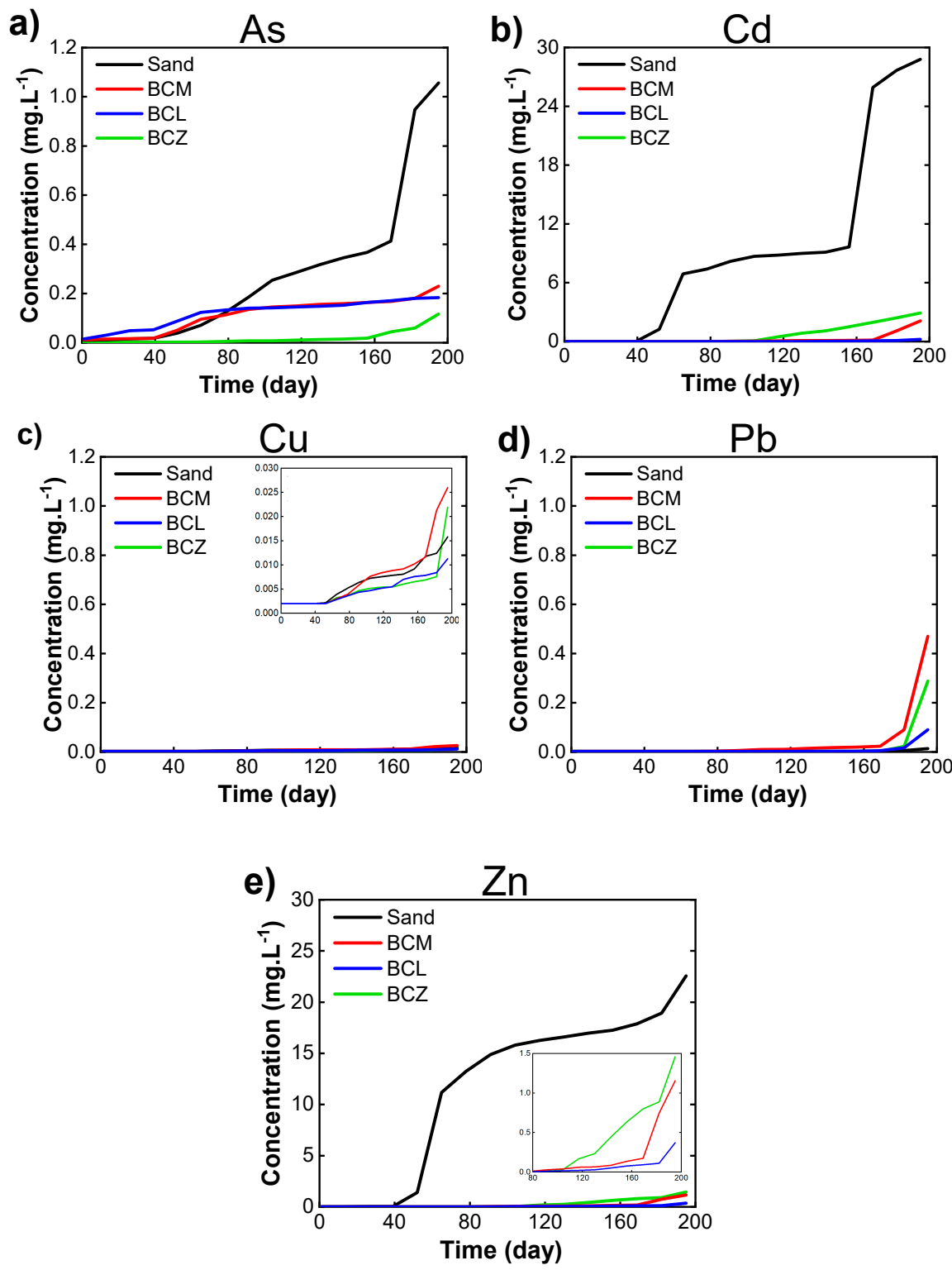

Figure 5. Concentration changes of (a) $\mathrm{As}$; (b) $\mathrm{Cd}$; (c) $\mathrm{Cu}$; (d) $\mathrm{Pb}$; and (e) $\mathrm{Zn}$ in the effluents from different column configurations (Sand, $\mathrm{BCM}, \mathrm{BCL}$, and $\mathrm{BCZ}$ ) with respect to time. 


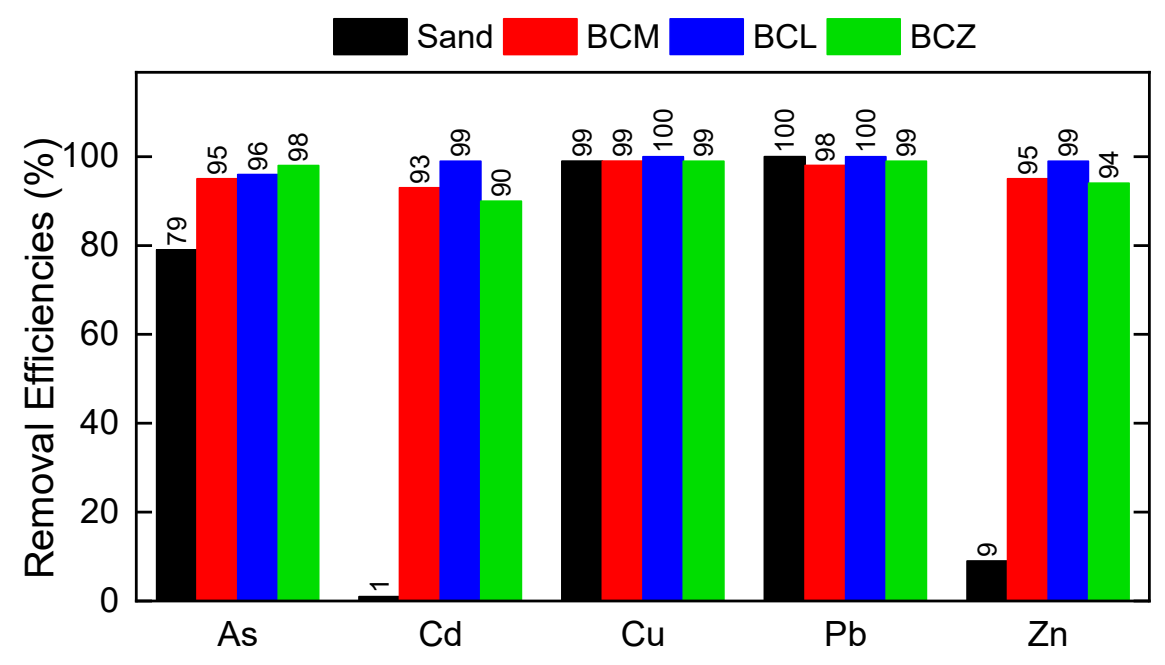

Figure 6. Metal removal efficiencies (\%) of different media configurations such as Sand, BCL, BCM, and $\mathrm{BCZ}$ for $\mathrm{As}, \mathrm{Cd}, \mathrm{Cu}, \mathrm{Pb}$, and $\mathrm{Zn}$.

\subsubsection{Metal/Metalloid Concentration Changes over Time}

Effluent metal/metalloid concentrations from each column configuration over time (Figure 5) reflected the removal performances of corresponding media with time. For example, arsenic (As) was efficiently removed in the BCZ column configuration as compared to other configurations. For example, arsenic effluent concentration after 160 days of dosing in BCZ (BC-nZVI layered column) was $0.016 \mathrm{mg} / \mathrm{L}$, whereas BCL and BCM exhibited 10-fold higher $(0.164 \mathrm{mg} / \mathrm{L})$ As concentrations at effluents. As showed the lowest removal in sand compared to other media configurations. As was primarily removed by surface complexations and electrostatic interactions to the functional groups (mainly $-\mathrm{OH}$ and $-\mathrm{COOH}$ ) on biochar and BC-nZVI [50]. Additionally, possible oxidation of nZVI was evident from the EDS results (Figure 3) on BC-nZVI, which increases the retention sites for As via surface complexations [51]. As attached in BCL and BCM columns due to the surface complexations with carboxyl and hydroxyl functional groups present on the biochar surface. The best configuration for efficient $\mathrm{Cd}$ removal was BCL followed by BCM and BCZ columns. Sand performance was poor for $\mathrm{Cd}$ removal, as it was for As. It indicates that the attachment of $\mathrm{Cd}$ to functional groups of biochar was stronger compared to the attachment to $\mathrm{nZVI}$ in the $\mathrm{BCZ}$ column. After 169 days of dosing, negligible $\left(0.07 \mathrm{mg} \cdot \mathrm{L}^{-1}\right)$ effluent concentrations of $\mathrm{Cd}$ were observed in BCL and BCM columns, whereas BCZ and sand columns released 1.96 and $27.68 \mathrm{mg} \cdot \mathrm{L}^{-1}$, respectively. Almost a complete breakthrough (influent concentration of $30 \mathrm{mg} \cdot \mathrm{L}^{-1}$ ) of Cd occurred in sand columns at 200 days.

Comparison of influent and effluent concentrations showed that all media configurations were efficient in removing $\mathrm{Cu}$; all effluent concentrations were $<0.027 \mathrm{mg} \cdot \mathrm{L}^{-1}$ compared to the influent concentration of $2.5 \mathrm{mg} \cdot \mathrm{L}^{-1}$ after 200 days of dosing. Surprisingly, sand showed similar removal capability compared to other column configurations regarding $\mathrm{Cu}$ and $\mathrm{Pb}$ removal. All media columns except sand were effective at the retention of zinc ( $\mathrm{Zn})$. The sand was the least effective material for $\mathrm{Zn}$ removal, showing a complete (released $22.56 \mathrm{mg} \cdot \mathrm{L}^{-1}$ vs. input $\left.25 \mathrm{mg} \cdot \mathrm{L}^{-1}\right)$ breakthrough after 195 days. The order of reduction potentials of $\mathrm{Pb} / \mathrm{Pb}^{2+}(+0.99 \mathrm{~V})>\mathrm{Cu} / \mathrm{Cu}^{2+}(+0.34 \mathrm{~V})>\mathrm{As}^{3+} / \mathrm{As}(-0.30 \mathrm{~V})>\mathrm{Fe}^{2+} / \mathrm{Fe}(\mathrm{s})$ $(-0.44 \mathrm{~V})$ explained the attachment of these metal ions to the nZVI and higher retention in the $\mathrm{BCZ}$ column. Functional groups on biochar also played an important role in retaining the metal ions in BCL and BCM columns.

\subsubsection{Removal Efficiencies of Media}

The metal/metalloid removal efficiencies (at 200 days) of each configuration were computed and are shown in Figure 6. Removal efficiencies showed that $\mathrm{Cu}$ and $\mathrm{Pb}$ were efficiently $(98-100 \%)$ removed in all combinations of media, attributed to their attachment 
efficiencies to media. $\mathrm{BCZ}$ does have magnetic characteristics $[52,53]$ which benefit copper adsorption, but the increased surface area of BCL has more effect on removal efficiency. $\mathrm{BCM}$ and sand removal efficiency can be explained by the same reasoning; BCM has a larger surface area than the sand; therefore, more sites for adsorption of copper. The adsorption mechanism of lead was dominated by complexation with active surface groups, precipitation, and cation exchange. The abundant functional groups on biochar in BCL can explain why it is effective in the adsorption of lead.

$\mathrm{BCZ}$ appeared to be the best at retaining the arsenic, with an average efficiency of $97.7 \%$ after 200 days of constant application at $5 \mathrm{~cm} /$ day. Under the same conditions, BCL averaged a removal efficiency of $96.3 \%$, followed by BCM at $95.4 \%$, and sand at $79.0 \%$. The influent concentration of arsenic was $5 \mathrm{mg} / \mathrm{L}$. Two main mechanisms in leaching arsenic through BC-nZVI are surface adsorption and intraparticle diffusion onto nZVI biochar complexes. This may explain why the BCZ performed better for the adsorption of arsenic than the other materials. Sand had the poorest removal efficiency of arsenic (79\%). Sand's low performance can be attributed to the lack of surface area for physical adsorption. SEM images of BC-nZVI confirmed that both iron and oxygen are present on biochar in high concentrations. Additionally, the surface complex with hydroxide groups from biochar increased the adsorption potential of arsenic on biochar surfaces.

Cadmium was effectively retained by all biochar mixtures, but sand showed a poor removal efficiency. The average removal efficiency for sand was only $1.2 \%$ compared to 90 , 93, and $99 \%$ in BCZ, BCM, and BCL, respectively. BCL had the best retention of cadmium with a removal efficiency of $99 \%$, and an effluent concentration of $0.216 \mathrm{mg} / \mathrm{L}$. The possible adsorption mechanisms of $\mathrm{Cd}$ by biochar are cation exchange, surface complexation, precipitation, and electrostatic interactions. Previous literature [54] found that plant-based biochar adsorption was dominantly controlled by cation exchange. All biochar media had a high removal efficiency of zinc, greater than $94 \%$ (Figure 6). The sand was found to be a poor adsorbent of zinc with a removal efficiency of $9 \%$, and effluent concentration of $22.6 \mathrm{mg} / \mathrm{L}$. BCL had the best removal efficiency at $99 \%$, followed by BCM $(95 \%)$ and BCZ $(94 \%)$.

Comparing the BCL and BCM column removal performances, the same biochar to the sand ratio ( $5 \%$ by weight) was used in preparation. The removal efficiency was similar between the two, with BCL being slightly more efficient than BCM ( 99 vs. $95 \%$ for $\mathrm{Zn}$ and 99 vs. $93 \%$ for $\mathrm{Cd}$ ). The only difference between the media was the distribution of biochar; the better performance of BCL can be attributed to higher retention in the biochar layer. The layer allows for more contact time between arsenic and biochar. The homogenous mixture of sand and biochar in BCM allowed the metal solution to pass with higher velocity through the media, and there was reduced contact time for physical adsorption in comparison to the BCL.

The exaggerated metal concentrations were a testament to biochar's heavy metal removal capabilities. In most cases, the metal concentrations in the stormwater solution were 100-1000 times greater than the first flush values found in Los Angeles [55]. The biochar media may be efficient for a substantial number of years given normal concentrations. Even sand had satisfactory removal efficiencies for some metals; however, sand did have the only breakthroughs seen in the experiment $(\mathrm{Cd}, \mathrm{Zn})$.

The assumption was that BCZ would outperform both BCL and BCM [9]. However, $B C L$ and $B C M$ 's better metal retention abilities can be attributed to the greater surface area associated with greater amounts of fine particles present in biochar, which increases physical adsorption. A significant surface area reduction was expected in BC-nZVI compared to biochar (used in BCL and BCM) during the synthesizing process (discussed in Section 2.1.1). The assumption is that $B C Z$ may have suffered from the cleaning process, losing fine particles when rinsed with ethanol to prevent excessive oxidation. However, even with the fine particle loss (substantially reduced surface area), BCZ outperformed other biochar combinations when analyzing arsenic retention; this can be attributed to surface complexations due to the functional groups and iron oxide present on BC-nZVI. 


\subsection{Model Investigations}

\subsubsection{Media Hydraulic Parameters}

Soil moisture data collected from sensors were entered into HYDRUS 2D software and inversely modeled to estimate media hydraulic parameters, which are shown in Table 3. Soil hydraulic parameters could successfully be estimated using HYDRUS 2D to predict unsaturated zone infiltrations [56,57].

Table 3. Hydraulic parameters determined by the HYDRUS 2D inverse modeling.

\begin{tabular}{ccccccc}
\hline Column & Media & $\theta_{\mathbf{r}}$ & $\theta_{\mathbf{s}}$ & $\boldsymbol{\alpha}$ & $\mathbf{n}$ & $\mathbf{K}_{\mathbf{s}}$ \\
\hline Sand & Only sand & 0.002 & 0.478 & 0.08 & 4.4433 & 711.169 \\
\hline \multirow{2}{*}{ BCM } & Biochar and sand mixture & 0.136 & 0.484 & 0.024 & 1.788 & 31.243 \\
\hline \multirow{2}{*}{ BCL } & Sand & 0.035 & 0.365 & 0.141 & 1.719 & 711.409 \\
& Biochar & 0.3 & 0.626 & 0.001 & 2.56 & 16.532 \\
\hline \multirow{2}{*}{ BCZ } & Sand & 0.035 & 0.365 & 0.069 & 2.226 & 710.76 \\
& BC-nZVI & 0.3 & 0.439 & 0.093 & 1.168 & 30.413 \\
\hline
\end{tabular}

Measured vs. modeled moisture contents (steady state) are shown in Figure S1a-d. The soil moisture content order was $\mathrm{BCL}>\mathrm{BCZ}>\mathrm{BCM}>$ sand. The order was based on the middle sensor readings, which was where biochar and nZVI biochar layers were located. The biochar layer had a moisture content of $64 \%$, nZVI was $39 \%$, biochar homogenous mixture was $27 \%$, and sand was $4.3 \%$ at steady states. To create free drainage at the bottom with rubber caps, the bottom cap had an elevated center and stored water. The storage of water was apparent when the bottom sensor in the sand column was higher than the other sensors. The sand column sensors one and two had a difference of $<0.5 \%$, verifying the assumption of storage in the bottom of the column. At steady state, sensor one, sensor two and sensor three were, $4.3,4.1$, and $25.3 \%$, respectively. The pure biochar layer was the best at retaining water, with the middle sensor reading $66.0 \%$ at a steady state. The biochar layer not only managed to retain a high amount of water but contributed to the moisture content and soil water retention of the sand layer above it. The sand layer above the biochar layer had a water content that was $12.0 \%$ at a steady state, more than double the control column of sand at the same sensor reading. Similar to the sand column, there was storage in the bottom of the column and the sensor located at the bottom of the column had a water content reading of $28.0 \%$ at a steady state; a value that was well over the free drainage value expected. The expectations were that BCM would have very similar water content values throughout the column given free drainage. $\mathrm{BCM}$ was comparable at the top sensor and the bottom sensor, at $26.6 \%$ and $20.5 \%$ at a steady state, respectively. Sensor three, located at the bottom of the column, had a water content value of $44.3 \%$ at a steady state, which was higher than the other sensors located in the top and middle of the column. This was another indication that free drainage was not accomplished and there was water storage in the bottom of the column. BCZ had a water content value of $40.8 \%$ at the middle sensor. The sensor located at the top of the column was $8.0 \%$ at steady state, indicating that the middle nZVI biochar layer affected the water content on the sand layer above. The sensor at the bottom of the column had a water content value of $35.4 \%$ at steady state. The sand model provided good results $\left(R^{2}=0.98\right)$ when the simulation was compared to the observed results.

\subsubsection{Metal/Metalloid Transport Model Outputs}

Solute transport was modeled using HYDRUS 2D (version 2.05) of the software. Standard Solute Transport was utilized with Water Flow to create the transport parameter, $\mathrm{K}_{\mathrm{d}}$. The model was run for 200 days using modeled hydraulic parameters (shown in Table 3). A linear isotherm approach was assumed to quantify $K_{d}$ values based on the measured metal concentrations and displayed in Table 4. Measured and modeled effluent metal concentrations at the end of the simulation are shown in Table S2. 
Table 4. Attachment coefficient of metals estimated from HYDRUS 2D for different column media.

\begin{tabular}{cccccc}
\hline \multirow{2}{*}{ Column } & \multicolumn{5}{c}{ Attachment Coefficient, $\mathbf{K}_{\mathbf{d}}\left[\mathbf{L} \cdot \mathbf{k g}^{-1}\right]$} \\
\cline { 2 - 6 } & $\mathbf{A s}$ & $\mathbf{C d}$ & $\mathbf{C u}$ & $\mathbf{P b}$ & $\mathbf{Z n}$ \\
\hline Sand & 14.6 & 9.5 & 18.5 & 19.9 & 10.9 \\
BCM & 16.6 & 16.1 & 19.3 & 18.2 & 16.6 \\
BCL & 22.5 & 44.9 & 21.5 & 25.9 & 36.7 \\
BCZ & 22.6 & 26.5 & 20 & 18.8 & 26 \\
\hline
\end{tabular}

According to the attachment coefficient $\left(\mathrm{K}_{\mathrm{d}}\right)$, BCL performed as the best media configuration for most of the metals considered for this study except As. Abundant carboxyl and hydroxyl functional groups on biochar, as evident from SEM-EDS and FTIR analyses, play an important role in the metal removal. It was also revealed that using the same amount of biochar in a layer performed better than a homogeneous mix. BCZ performed better in As removal, indicated by the high affinity of As to nZVI, and BC-nZVI is therefore an efficient medium for As removal from stormwater.

Moreover, HYDRUS 2D creates animations that illustrate the metal solutions' movement through soils. In Figure 7, the movement of the metal solution is shown after 100 days and then at the end of the simulation (200 days). The concentration is color-coded so that the difference in concentration can be seen as it progresses over time. Model outputs displayed the metal transports and retention in columns through different media at any time within simulation duration. For example, Figure 7 displays the metal transport along the column at 100 and 200 days.

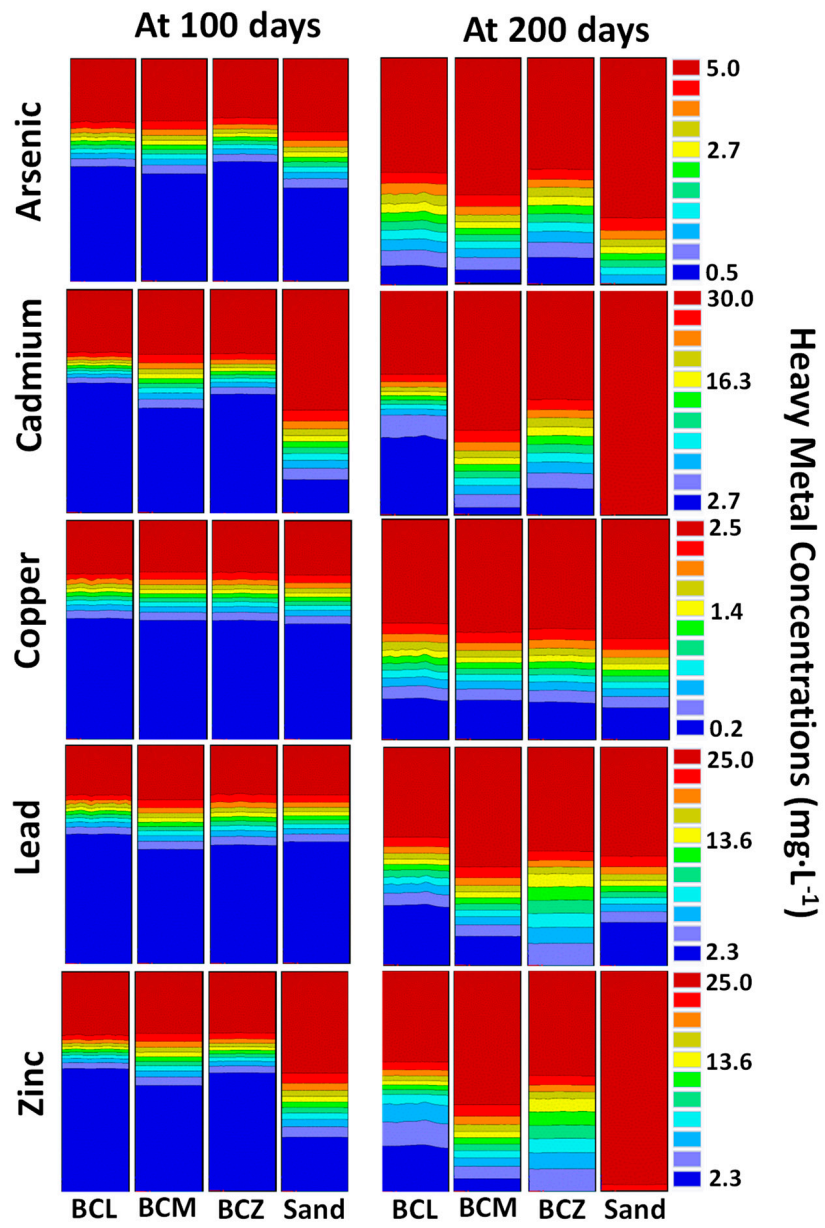

Figure 7. Transport of metals through columns at 100 days and 200 days via HYDRUS 2D modeling. 


\section{Conclusions}

Urban runoff is a major concern as the population grows and impervious areas expand, leaving less surface area for treatment by infiltration. Bio-retention media have the potential to filter runoff for many constituents including heavy metals. This work focused on biochar and nZVI modified biochar media for their metal remediation potential compared to other common media used for this purpose. Arsenic and dissolved heavy metals $(\mathrm{Cd}, \mathrm{Cu}, \mathrm{Pb}$, and $\mathrm{Zn}$ ) were used in concentrations higher than normal to assess the potential differences in removal rates between media configurations. Sand is a material that is traditionally used as bioretention media; it showed efficient removal of $\mathrm{Cu}$ and $\mathrm{Pb}$ in this study. However, sand evidently has a shorter breakthrough period when it comes to As, $\mathrm{Cd}$, and $\mathrm{Zn}$. The column study demonstrated that sand combined with biochar or nZVI modified biochar (BC-nZVI) in any of the combinations, either as a homogeneous (BCM) or as layered mixture (BCL or $\mathrm{BCZ}$ ), showed high efficiency to remove metals from stormwater runoff compared to the homogeneous sand. Arsenic had a noticeable affinity for nZVI, which was validated by efficient removal in BCZ, whereas BCM and BCL performed efficiently regarding Cd and Zn removal. Biochar's metal retention abilities can be attributed to the greater surface area, which increases physical adsorption sites. $\mathrm{Pb}$ and $\mathrm{Cu}$ were efficiently removed by all media configurations, including homogeneous sand. This work was not limited to heavy metal retention but provided insight into biochar and nZVI modified biochar hydraulic potential and water retention abilities. The moisture sensor data that were recorded to assist in modeling hydraulic parameters demonstrated that BCL had the most retention time from the initial experiment startup, followed by $\mathrm{BCM}>\mathrm{BCZ}>$ sand. The porous structure of biochar responsible for enhanced water retention capabilities was filled with the nZVI particles, limiting water retention in BC-nZVI. Thus, there was a noticeable loss in water retention potential in nZVI biochar, and the loss of pore space in BCM and BCZ decreased retention and contact time with biochar functional groups, limiting pollutant removal. Numerical simulations using HYDRUS 2D displayed the movement of dissolved metals in each media configuration over the 200 days. This study showed that the application of biochar as a bioretention media would enhance stormwater treatment and reduce heavy metal discharge to groundwater and streams.

Supplementary Materials: The following are available online at https:/ /www.mdpi.com/article/10 $.3390 /$ pr9050860/s1, Table S1: FTIR spectra associated with functional group, Figure S1: Moisture contents measured using the sensors and inversely modeled using HYDRUS 2D, Table S2: Final effluent metal concentrations from each column: measured vs. modeled.

Author Contributions: Conceptualization, R.V., M.G. and M.S.H.; methodology, R.V., M.G. and M.S.H.; software, R.V.; validation, R.V.; formal analysis, R.V. and M.S.H.; investigation, R.V. and M.S.H.; resources, M.G.; data curation, R.V. and M.S.H.; writing-original draft preparation, M.S.H. and R.V.; writing-review and editing, M.S.H., R.V. and M.G.; visualization, R.V. and M.S.H.; supervision, M.G.; project administration, M.G.; funding acquisition, M.G. All authors have read and agreed to the published version of the manuscript.

Funding: This research was funded by Nelson Foundation Grant, Water Resources Foundation, and Civil and Environmental Engineering Department, South Dakota School of Mines and Technology.

Institutional Review Board Statement: Not applicable.

Informed Consent Statement: Not applicable.

Data Availability Statement: This study did not report any data.

Acknowledgments: The authors would like to acknowledge Forest Cooper for his support in setting up the column frame.

Conflicts of Interest: The authors declare no conflict of interest. 


\section{References}

1. Goonetilleke, A.; Thomas, E.; Ginn, S.; Gilbert, D. Understanding the role of land use in urban stormwater quality management. J. Environ. Manag. 2005, 74, 31-42. [CrossRef]

2. Mohammed, A.S.; Kapri, A.; Goel, R. Heavy metal pollution: Source, impact, and remedies. In Biomanagement of MetalContaminated Soils; Springer: Dordrecht, The Netherlands, 2011; pp. 1-28.

3. Mulligan, C.; Yong, R.; Gibbs, B. Remediation technologies for metal-contaminated soils and groundwater: An evaluation. Eng. Geol. 2001, 60, 193-207. [CrossRef]

4. Su, C. A review on heavy metal contamination in the soil worldwide: Situation, impact and remediation techniques. Environ. Skept. Crit. 2014, 3, 24-38.

5. Jang, A.; Seo, Y.; Bishop, P.L. The removal of heavy metals in urban runoff by sorption on mulch. Environ. Pollut. 2005, 133, 117-127. [CrossRef]

6. Cárdenas, G.; Orlando, P.; Edelio, T. Synthesis and applications of chitosan mercaptanes as heavy metal retention agent. Int. J. Biol. Macromol. 2001, 28, 167-174. [CrossRef]

7. Erdem, E.; Karapinar, N.; Donat, R. The removal of heavy metal cations by natural zeolites. J. Colloid Interface Sci. 2004, 280, 309-314. [CrossRef]

8. Brown, P.; Jefcoat, I.A.; Parrish, D.; Gill, S.; Graham, E. Evaluation of the adsorptive capacity of peanut hull pellets for heavy metals in solution. Adv. Environ. Res. 2000, 4, 19-29. [CrossRef]

9. Hasan, S.; Geza, M.; Vasquez, R.; Chilkoor, G.; Gadhamshetty, V. Enhanced heavy metal removal from synthetic stormwater using nanoscale zerovalent iron-modified biochar. Water Air Soil Pollut. 2020, 231, 1-15. [CrossRef]

10. Reddy, K.R.; Xie, T.; Dastgheibi, S. Evaluation of Biochar as a potential filter media for the removal of mixed contaminants from urban storm water runoff. J. Environ. Eng. 2014, 140, 04014043. [CrossRef]

11. Komkiene, J.; Baltrenaite, E. Biochar as adsorbent for removal of heavy metal ions [Cadmium (II), Copper (II), Lead (II), Zinc (II)] from aqueous phase. Int. J. Environ. Sci. Technol. 2016, 13, 471-482.

12. Shojaeizadeh, A.; Geza, M.; McCray, J.; Hogue, T.S. Site-scale integrated decision support tool (i-DSTss) for stormwater management. Water 2019, 11, 2022. [CrossRef]

13. Shojaeizadeh, A.; Geza, M.; Bell, C.; McCray, J.; Hogue, T. A site-scale tool for performance-based design of stormwater best management practices. Water 2021, 13, 844. [CrossRef]

14. Li, H.; Davis, A.P. Water quality improvement through reductions of pollutant loads using bioretention. J. Environ. Eng. 2009, 135, 567-576. [CrossRef]

15. Winston, R.J.; Dorsey, J.D.; Hunt, W.F. Quantifying volume reduction and peak flow mitigation for three bioretention cells in clay soils in Northeast Ohio. Sci. Total Environ. 2016, 553, 83-95. [CrossRef]

16. Chapman, C.; Horner, R.R. Performance assessment of a street-drainage bioretention system. Water Environ. Res. 2010, 82, 109-119. [CrossRef]

17. Kobya, M.; Demirbas, E.; Senturk, E.; Ince, M. Adsorption of heavy metal ions from aqueous solutions by activated carbon prepared from apricot stone. Bioresour. Technol. 2005, 96, 1518-1521. [CrossRef]

18. Kabir, T.; Hasan, M.S.; Das, P. Applicability of activated carbon filtration in surface water treatment. Asian J. Innov. Res. Sci. Eng. Technol. 2016, 1, 1-6.

19. Akhil, D.; Lakshmi, D.; Kartik, A.; Vo, D.-V.N.; Arun, J.; Gopinath, K.P. Production, characterization, activation and environmental applications of engineered biochar: A review. Environ. Chem. Lett. 2021, 1-37. [CrossRef]

20. Ashoori, N.; Teixido, M.; Spahr, S.; LeFevre, G.H.; Sedlak, D.L.; Luthy, R.G. Evaluation of pilot-scale biochar-amended woodchip bioreactors to remove nitrate, metals, and trace organic contaminants from urban stormwater runoff. Water Res. 2019, 154, 1-11. [CrossRef]

21. Mohanty, S.K.; Valenca, R.; Berger, A.W.; Yu, I.K.; Xiong, X.; Saunders, T.M.; Tsang, D.C. Plenty of room for carbon on the ground: Potential applications of biochar for stormwater treatment. Sci. Total Environ. 2018, 625, 1644-1658. [CrossRef]

22. Ulrich, B.A.; Im, E.A.; Werner, D.; Higgins, C.P. Biochar and activated carbon for enhanced trace organic contaminant retention in stormwater infiltration systems. Environ. Sci. Technol. 2015, 49, 6222-6230. [CrossRef]

23. Lehmann, J.; Joseph, S. (Eds.) Biochar for Environmental Management: Science, Technology and Implementation; Routledge: London, UK, 2015.

24. Woolf, D.; Amonette, J.E.; Street-Perrott, F.A.; Lehmann, J.; Joseph, S.G. Sustainable biochar to mitigate global climate change. Nat. Commun. 2010, 1, 56. [CrossRef]

25. Ahmad, M.; Rajapaksha, A.U.; Lim, J.E.; Zhang, M.; Bolan, N.; Mohan, D.; Vithanage, M.; Lee, S.S.; Ok, Y.S. Biochar as a sorbent for contaminant management in soil and water: A review. Chemosphere 2014, 99, 19-33.

26. Liang, B.; Lehmann, J.; Solomon, D.; Kinyangi, J.; Grossman, J.; O’Neill, B.; Skjemstad, J.O.; Thies, J.; Luizão, F.J.; Petersen, J.; et al. Black carbon increases cation exchange capacity in soils. Soil Sci. Soc. Am. J. 2006, 70, 1719-1730. [CrossRef]

27. Nzediegwu, C.; Arshad, M.; Ulah, A.; Naeth, M.A.; Chang, S.X. Fuel, thermal and surface properties of microwave-pyrolyzed biochars depend on feedstock type and pyrolysis temperature. Bioresour. Technol. 2021, 320, 124282. [CrossRef]

28. Li, H.; Dong, X.; da Silva, E.B.; de Oliveira, L.M.; Chen, Y.; Ma, L.Q. Mechanisms of metal sorption by biochars: Biochar characteristics and modifications. Chemosphere 2017, 178, 466-478. [CrossRef]

29. Zhang, W.-X. Nanoscale iron particles for environmental remediation: An overview. J. Nanopart. Res. 2003, 5, 323-332. [CrossRef] 
30. Coston, J.A.; Fuller, C.C.; Davis, J.A. $\mathrm{Pb}^{2+}$ and $\mathrm{Zn}^{2+}$ adsorption by a natural aluminum- and iron-bearing surface coating on an aquifer sand. Geochim. Cosmochim. Acta 1995, 59, 3535-3547. [CrossRef]

31. Agrawal, A.; Sahu, K. Kinetic and isotherm studies of cadmium adsorption on manganese nodule residue. J. Hazard. Mater. 2006, 137, 915-924. [CrossRef]

32. Hasan, S.; Geza, M.; Petersen, J.B.; Gadhamshetty, V. Graphene oxide transport and retention in biochar media. Chemosphere 2021, 264, 128397. [CrossRef]

33. Shu, H.-Y.; Chang, M.-C.; Chen, C.-C.; Chen, P.-E. Using resin supported nano zero-valent iron particles for decoloration of Acid Blue 113 azo dye solution. J. Hazard. Mater. 2010, 184, 499-505. [CrossRef]

34. Zhou, Y.; Gao, B.; Zimmerman, A.R.; Chen, H.; Zhang, M.; Cao, X. Biochar-supported zerovalent iron for removal of various contaminants from aqueous solutions. Bioresour. Technol. 2014, 152, 538-542. [CrossRef]

35. Tian, J.; Jin, J.; Chiu, P.C.; Cha, D.K.; Guo, M.; Imhoff, P.T. A pilot-scale, bi-layer bioretention system with biochar and zero-valent iron for enhanced nitrate removal from stormwater. Water Res. 2019, 148, 378-387. [CrossRef]

36. Lau, A.Y.; Tsang, D.C.; Graham, N.J.; Ok, Y.S.; Yang, X.; Li, X.-D. Surface-modified biochar in a bioretention system for Escherichia coli removal from stormwater. Chemosphere 2017, 169, 89-98. [CrossRef]

37. Amen, R.; Bashir, H.; Bibi, I.; Shaheen, S.M.; Niazi, N.K.; Shahid, M.; Hussain, M.M.; Antoniadis, V.; Shakoor, M.B.; Al-Solaimani, S.G.; et al. A critical review on arsenic removal from water using biochar-based sorbents: The significance of modification and redox reactions. Chem. Eng. J. 2020, 396, 125195. [CrossRef]

38. Reddy, K.R.; Dastgheibi, S.; Cameselle, C. Mixed versus layered multi-media filter for simultaneous removal of nutrients and heavy metals from urban stormwater runoff. Environ. Sci. Pollut. Res. 2021, 28, 7574-7585. [CrossRef]

39. Yan, J.; Han, L.; Gao, W.; Xue, S.; Chen, M. Biochar supported nanoscale zerovalent iron composite used as persulfate activator for removing trichloroethylene. Bioresour. Technol. 2015, 175, 269-274. [CrossRef]

40. Grebel, J.E.; Mohanty, S.K.; Torkelson, A.A.; Boehm, A.B.; Higgins, C.P.; Maxwell, R.M.; Nelson, K.L.; Sedlak, D.L. Engineered infiltration systems for urban stormwater reclamation. Environ. Eng. Sci. 2013, 30, 437-454. [CrossRef]

41. Grebel, J.E.; Charbonnet, J.A.; Sedlak, D.L. Oxidation of organic contaminants by manganese oxide geomedia for passive urban stormwater treatment systems. Water Res. 2016, 88, 481-491. [CrossRef]

42. Liu, Q.; Wu, L.; Gorring, M.; Deng, Y. Aluminum-impregnated biochar for adsorption of arsenic (V) in urban stormwater runoff. J. Environ. Eng. 2019, 145, 04019008. [CrossRef]

43. Li, H.; Liu, Y.; Chen, Y.; Wang, S.; Wang, M.; Xie, T.; Wang, G. Biochar amendment immobilizes lead in rice paddy soils and reduces its phytoavailability. Sci. Rep. 2016, 6, 31616. [CrossRef]

44. Jain, M.S.; Jambhulkar, R.; Kalamdhad, A.S. Biochar amendment for batch composting of nitrogen rich organic waste: Effect on degradation kinetics, composting physics and nutritional properties. Bioresour. Technol. 2018, 253, 204-213. [CrossRef]

45. Šimůnek, J.; van Genuchten, M.; Sejna, M. HYDRUS Technical Manual: The HYDRUS Software Package for Simulating the Two-and Three Dimensional Movement of Water, Heat and Multiple Solutes in Variably-Saturated Porous Media; Technical Manual Version 2; PC-Progress: Prague, Czech Republic, 2012.

46. Mualem, Y. A new model for predicting the hydraulic conductivity of unsaturated porous media. Water Resour. Res. 1976, 12, 513-522. [CrossRef]

47. Van Genuchten, M.T. A closed-form equation for predicting the hydraulic conductivity of unsaturated soils. Soil Sci. Soc. Am. J. 1980, 44, 892-898. [CrossRef]

48. Lara, N.; Figueroa, L.; Carvajal, F.; Zapata, Y.; Urbina, C.; Escobar, H. Quantitative differentiation between soil organic carbon and biochar carbon in Aridisol. Int. J. Agric. Nat. Resour. 2013, 40, 387-395.

49. Ahangaran, F.; Hassanzadeh, A.; Nouri, S. Surface modification of $\mathrm{Fe}_{3} \mathrm{O}_{4} @ \mathrm{SiO}_{2}$ microsphere by silane coupling agent. Int. Nano Lett. 2013, 3, 23. [CrossRef]

50. Niazi, N.K.; Bibi, I.; Shahid, M.; Ok, Y.S.; Burton, E.D.; Wang, H.; Shaheen, S.M.; Rinklebe, J.; Lüttge, A. Arsenic removal by perilla leaf biochar in aqueous solutions and groundwater: An integrated spectroscopic and microscopic examination. Environ. Pollut. 2018, 232, 31-41. [CrossRef]

51. Liu, X.; Gao, M.; Qiu, W.; Khan, Z.H.; Liu, N.; Lin, L.; Song, Z. Fe-Mn-Ce oxide-modified biochar composites as efficient adsorbents for removing As(III) from water: Adsorption performance and mechanisms. Environ. Sci. Pollut. Res. 2019, 26, 17373-17382. [CrossRef]

52. Han, Z.; Sani, B.; Mrozik, W.; Obst, M.; Beckingham, B.; Karapanagioti, H.K.; Werner, D. Magnetite impregnation effects on the sorbent properties of activated carbons and biochars. Water Res. 2015, 70, 394-403. [CrossRef]

53. Zhu, S.; Ho, S.-H.; Huang, X.; Wang, D.; Yang, F.; Wang, L.; Wang, C.; Cao, X.; Ma, F. Magnetic nanoscale zerovalent iron assisted biochar: Interfacial chemical behaviors and heavy metals remediation performance. ACS Sustain. Chem. Eng. 2017, 5, 9673-9682. [CrossRef]

54. Harvey, O.R.; Herbert, B.E.; Rhue, R.D.; Kuo, L.-J. Metal interactions at the biochar-water interface: Energetics and structuresorption relationships elucidated by flow adsorption microcalorimetry. Environ. Sci. Technol. 2011, 45, 5550-5556. [CrossRef]

55. Stenstrom, M.K.; Kayhanian, M. First Flush Phenomenon Characterization; California Department of Transportation Division of Environmental Analysis: Sacramento, CA, USA, 2005. 
56. Geza, M.; Deb, S.K.; Leinauer, B.; Stanek, S.; Sevostianova, E.; Serena, M. Modeling $\mathrm{NO}_{3}-\mathrm{N}$ leaching during establishment of turfgrasses irrigated with tailored reclaimed water. Vadose Zone J. 2021, e20112. [CrossRef]

57. Geza, M.; Lowe, K.S.; Huntzinger, D.N.; McCray, J.E. New conceptual model for soil treatment units: Formation of multiple hydraulic zones during unsaturated wastewater infiltration. J. Environ. Qual. 2013, 42, 1196-1204. [CrossRef] 